\title{
To Explore the Marriage Ban Conditions on the Sight of Social Reformation of the Tang and Song Period
}

\author{
Chen Xiuping \\ (Three Gorges University of China, Yichang Hubei, 443002)
}

\begin{abstract}
.
During the Tang and Song Dynasty, with the development of commodity economy, everything changed greatly such us social ideology and the concept of value. These changes were shown through all kinds of systems including political systems and legal systems and cultural systems. There are both similarities and differences in the marriage ban conditions of Tang and Song Dynasty. The article compared the marriage ban conditions of Tang and Song Dynasty, to find the similarities and differences and analyze the causes, in order to find the influence which the social reformation bring out to the marriage culture.
\end{abstract}

Key words: The Tang Dynasty; The Song Dynasty; marriage ban conditions; the social reformation

During the Tang and Song Dynasty, with the development of commodity economy, everything changed greatly such us social ideology and the concept of value. These changes were shown through all kinds of systems including political systems and legal systems and cultural systems.

The marriage ban conditions, that is the marriage negative conditions or the legal obstacles of marriage, it is the legal situation to ban the marriage. There are both similarities and differences in the marriage ban conditions of Tang and
Song Dynasty.

1. The marriage ban conditions of Tang Dynasty

The marriage ban conditions of Tang Dynasty are thorough and the contents are abundant, it mainly included the principle of forbidding marriage between people of the same surname, the marriage between people who are relatives, the marriage between noble and the beneath, the marriage of people who has ever gotten married.

1.1 To forbid the marriage between people of the same surname

As early as Western Zhou Dynasty, there is such a tradition as forbidding marriage between people of the same surname in China. Spring and Autumn Annals said: “The man who doesn't marry surname woman pay attention to ethics, to prevent ministries and the same as the beasts. "The ban was written in law books in Tang Dynasty, the family and marriage of the Tang Code: "The man who married the same surname will be sentenced to two years in prison. Above the garb will be found guilty of crime of rape...... and will be sentenced to divorce. "The reasons not because of ethics but also physiological factors. With the change of the source of surname, the same surname is not necessarily related, so the code limited scope of the same surname in Tang Dynasty, as the professor Jin-Mei said: "The Tang corrected the extremism of 
forbidding marriage between people of the same surname, and enacted the ban of the same common surname instead, so as to realize the second leap in Chinese history of the institution of marriage.

\subsection{To forbid the marriage among the relatives}

The marriage won't be allowed among the relatives in Tang Dynasty including the marriage of statue of generation with low generation and marry the clan's wife.

The range of relatives that won't be allowed to get marriage including the mourning, the half, the daughter from wife and her pre-husband, the aunt, etc. According to this rule, whatever the relationship among them is mourning or non-mourning, as long as it is the senior or the junior, they won't be permitted to get marriage. Otherwise, they will be sentenced to crime and divorce.

To maintain the family ethics, the Tang Code prevented to marry the clan's wife, its aim is to maintain the inner order strictly.

\section{3 To forbid the marriage between the good person and the mean person}

On the question of marriage in the Tang Dynasty, it forbad the good person marry the mean person. The good person main body was farmers, the mean person mainly was maid-servants, the maid-servants were private property and the status was low. Once the mean person marry the good person, he would be sentenced to beating 100 , the maid-servant was found guilty of theft if she privately married the good person. Thus it can be seen, the marriage system of Tang Dynasty paid attention to protect the identity order and the feudal hierarchy.

\subsection{A man who had a wife no longer married}

Monogamy is an ancient marriage principle in our country, the Tang Dynasty is no exception, and it is forbidden the man who had a wife to marry again. A wife asked a man only own one wife, this is what the patriarchal clan system means.

\subsection{Forbid to rape in marriage}

The Tang Dynasty denied and harsh penalized the rape marriage. It can be seen from this rule "divorce even gave birth" that The Tang Dynasty had the determination and attitude to prevent the rape marriage.

2. The marriage ban conditions of Song Dynasty

2. 1 To forbid the marriage between people of the same surname.

The ban marriage of Song Dynasty had development on the basis of inheritance of Tang Dynasty. The Song Dynasty continued followed the rules of Tang Dynasty, still insisted on forbid ding the marriage between people of the same surname. The rules appeared in The Song Code.

To forbid the marriage between people of the same surname in Song Dynasty belonged to the same common surname, it mainly referred to the relatives can't get married who originated from common ancestor, if only had the same surname but not originated from common ancestor, they wouldn't be forbidden to get married.

\subsection{To forbid the marriage between ethnic groups.}

Since Song regime established, it was constantly threatened by the northern nationalities, with the coexistence of the minority regimes of Liao, Jin and Ixia.etc. Such social background to reflect on the institution 
of marriage is prohibited the Han and other ethnic intermarriage in the Song dynasty, namely ethnic marriage is prohibited.

In this regard, the court physically, it cut off the practice that married the minority leader since the Han and Tang dynasty.

\subsection{To forbid the marriage between} the good person and the mean person.

The Song Dynasty banned the marriage between the good person and the mean person in the form of law and increasingly strict, the legal system also increasingly perfect.

The Song Dynasty strictly rank, status, and the corresponding rights and obligations relations of the good person and the mean person, it asked people to "each in its points, keep its points", may not be insurmountable. However, along with the rapid development of the commodity economy in the Song Dynasty, the pursuit of wealth to become people's important target, the pursuit of wealth led to marriages between the good person and the mean person. The intermarriage destroyed the social hierarchy, therefore, the Song Dynasty constantly enacted laws to reiterate the ban. The Song Code on the basis of the relevant provisions in the Tang Code, it had increased the scope of the mean person, increased penalties for the marriage between the good person and the mean person.

\subsection{A man who had a wife no longer married.}

The Song Code forbad the man who had a wife to marry again. It asked a man can only marry a legal wife, otherwise, the man would be severely depressed by law.

\subsection{Forbid to rape in marriage.}

Though the Song dynasty rulers born of Wu Hang, they met the needs of its rule of Confucianism into the political rule of law at the beginning of the regime, they forbad to rape in marriage. In order to maintain their parents' rights in the children's marriage, the Song Code made a clear regulation that the rape marriage would be sentenced to divorce.

\section{The similarities and differences and the reasons of the marriage ban conditions}

\subsection{The similarities and the reasons.}

3.1.1 To forbid the marriage between people of the same surname and the marriage among the relatives.

Before the Western Zhou, Confucianism had no ban of the marriage between people of the same surname. After the Zhou Dynasty, all dynasties made this condition as marriage ban.

To forbid the marriage between people of the same surname and the marriage among the relatives have scientific basis, the men and women related close to get married, easy to pass both physical and mental defects to their children, is not conducive to racial flourish and prosperity. Though People in the Western Zhou dynasty cannot accurately cognize the dangers of consanguineous mating from the perspective of science, they had certain simple cognitive of the nature rules related to the marriage law.

To forbid the marriage between people of the same surname and the marriage among the relatives is also a patriarchal ethics requirement. The aim of Duke Zhou made ritual was to make the life of people to meet the 
requirements of the patriarchal ethic order. In accordance with the rules of order at the time, in the field of marriage, it placed emphasis on male, emphasize distinguishing between men and women, sequencing between senior and junior, don't allow "incest" behavior among relatives resolutely.

To forbid the marriage between people of the same surname and the marriage among the relatives, not only comply with the laws of nature, and also can achieve the aim of determining the birthright, distinguishing between men and women, preventing ministries, it had played a very important role in maintaining the order of family and state ruling order.

3.1.2 To forbid the marriage between the good person and the mean person.

The thought of forbidding the marriage between the good person and the mean person had been formed early, not only was approved by the customs but also absorbed by legal norms.

Lenin said: "the difference between classes is also fixed with hierarchies of residents, and determines the special legal status in the country for each class." In the feudal society, the different grades in different position, own different rights. In order to maintain their vested interests, the higher level people maintained their existing status through a variety of ways, strictness of social hierarchy can be imagined.

Because of the need for maintaining strict hierarchy in the Tang and Song Dynasty, the Tang and the Song Code stated explicitly that the good person and the mean person can't get married.
3.1.3 A man who had a wife no longer married.

Since the Zhou dynasty in ancient China, a husband and a wife, is the basic principle of Chinese marriage system. Ancient Chinese marriage etiquette will be compared to the moon and sun, the sun born in the east, the moon born in the west, compare the moon and sun to Yin and Yang, thus draw the conclusion that husband is Yang and wife is Yin. At the same time, accompanied by the sun and the moon, together constitute the alternation of day and night, it is an undeniable objective laws, the laws of nature to human marriage is to require a husband and a wife living together permanently.

\section{2 the differences and the reasons.}

Mr Qian-Mu said, "To talk about changes of ancient and modern society, the most important is the Song Dynasty. The society before Song can be called ancient China, and after the Song Dynasty is the China for posterity... so in terms of the Song Dynasty, the politics and economy, society and life changed more than before." From Tang to Song Dynasty, the institution of marriage ban conditions, from clear legal norms to social customs and habits had taken place some significant changes.

3.2. 1 To carry out united marriage in Tang Dynasty but forbid the marriage between ethnic groups in Song Dynasty.

The Tang Dynasty was the era of prosperity economy, developed culture in the history of China, and it was a relatively open era in Chinese history. At that time, because of the need for maintaining national unity, the Tang government pursued the policy of united by marriage to other ethnic groups, the policy was used more frequently than 
any dynasty before. In Tang Dynasty Vigorously promote the interracial marriage, promoted the communication and progress of all ethnic groups, promoted the great unity of all ethnic groups, and consolidate the political rule of Tang Dynasty .

The attitude of ethnic intermarriage, radical changes have taken place in the Song Dynasty. The Song Dynast was harassed by minority regime of the Liao, Jin and Ixia dynasties which was being located in the north, the border problem had always been existed since its founding, and to make the country rich and its military force efficient, the Song Dynasty prompted commodity economy continual development through internal series reform. In this big social background, the Song Dynasty adopted a prohibited strategy of ethnic intermarriage within the territory of the Han nationality with the Ixia, Liao and Jin.

3.2.2 The different attitude of marriage between cousins in Tang and Song dynasty.

The Tang Dynasty did not ban the marriage between cousins, they thought the marriage between cousins make the relative relationship closer and make private property not run off, both in the imperial family and the popular people, cross-cousin siblings or maternal cousin marriage phenomenon more familiar. The Song Dynasty banned the marriage, The Song Code regulated: "the marriage between cousins, to staff one hundred, divorce." Zhu Xi strongly opposed the marriage, thought it is one of the important reasons to make the pecking chaos and ethical disorder".

From the Tang Dynasty to Song Dynasty, the attitude of marriage between cousins is different, partly because the Tang Dynasty has the openness and forgiveness, but, Song Dynasty society prevailed "Neo-Confucianism".

3.2.3 The changes of marriage between the good person and the common person from the Tang Dynasty to Song Dynasty.

As mentioned above, the legal norms of marriage between the good person and the common person were clearly defined in both Tang Dynasty and Song Dynasty. However, for the execution of legal norms, some changes have taken place from the Tang Dynasty to Song Dynasty.

Overall, the Tang Dynasty strictly implemented policy of forbidding marriage between the good person and the common person. But in the Song Dynasty, with the further improvement of imperial civil service examination system and the rapid development of commodity economy, the system increasingly flabby, the concept of the marriage gradually was broken. The system increasingly flabby is closed with the rapid development of commodity economy in Song Dynasty.

\section{Conclusions}

The Social change of Tang and Song dynasty firstly embodies in the field of economic, social and economic development is the material basis of marriage system change. In Tang and Song dynasty, with the development and prosperity of commodity economy, new social forces - the rich formed, social form of life had changed, people's values concept had changed, too. As the change of big land ownership, as well as the improvement of the imperial civil service examination system, the development of commodity economy, 
the original gate cremation of foundering, plus many former ordinary who rose through the imperial examination among the ruling group, reflect on the marriage, from "family marriage" to "wealth marriage". And the system of ordinary not marry hierarchical dying, the system gradually collapse, "the marriage between the good person and the common person " ban gradually loosening.

The Social change of Tang and Song dynasty secondly reflected in politics, the political demand also affects the marriage policy formulation. Tang generation, political correctness, social stability, economic prosperity, cultural prosperity and military power, prevailed intermarriage, already shows the magnificent tolerance of Tang, and maintain the solidarity and unity of many nationalities. Song generation, long borders were threatened by alien harassment, combined with their own economic power, in order to "lose money" instead of "united marriage", in order to exchange the peace of the border.

The Social change of Tang and Song dynasty was also embodied in the field of ideology, social ideology is also affected the formulation and implementation of the institution of marriage. The Tang Dynasty had the openness, the Song Dynasty society prevailed "Neo-Confucianism". So, the Tang Dynasty allowed the marriage between cousins, but the Song Dynasty society forbad the marriage between cousins.

To sum up, in the Tang and Song dynasties, the forbidden conditions such as "same surname not marriage", "close relatives don't marry" and "a man has wife no more marriage", because of its usage in the interest of the family, a major role of state patriarchal order, had been widely used. With the change of The Times, the series changes have taken place. The influence of the social change of Tang and Song dynasties to Tang and Song dynasty marriage system is enormous.

\section{References}

[1]Zhangsun wuji, “The Tang Code" , Zhonghua publishing houses,pp.269-270, 1983.

[2]Xue- Meiqing, “The Song Code”, law Press China,pp. 253-254, 1999.

[3]Tuo Tuo, “The history of Song” , Zhonghua publishing houses,pp.98, 1981.

[4]Li Tao, "Continue Zi Zhi Tong Jian Chang Bian" ,Shanghai ancient books publishing houses,pp.3871, 1986.

[5]Cheng Peng, “The History of Chinese Marriage " , Zhonghua publishing houses,pp.421, 1990.

[6]Zheng Tianting, "Selected From Zuozhuan ” , Zhonghua publishing houses,pp.87, 1963. 